\title{
ECONOMIC COMPARISON OF BEEF PRODUCTION SYSTEMS IN THE EU
}

Artur Wilczynski ${ }^{1,}$ PhD assist.prof

${ }^{1}$ West Pomeranian University of Technology Szczecin, Poland

\begin{abstract}
The production system is one of the determinants of the economic situation and the way of farm management. This also applies to farms involved in the production of beef, which are located on the territory of the European Union. European farms are diversified in terms of the origin of calves used for fattening and the way of breeding beef cattle. The aim of the undertaken research was to indicate the differences in production costs and profitability of farms characterised by various beef production systems. The analysis used data from the agri benchmark Beef and Sheep network, with a research team including employees of West Pomeranian University of Technology in Szczecin. The conducted research shows that there is a dependence between production costs and the distinguished beef production systems. However, taking into account net cash farm income, it cannot be unequivocally shown that the cow-calf farms are characterised by higher profitability than the farms based on cattle from dairy production.
\end{abstract}

Key words: typical farms, production costs, profitability.

JEL code: Q12, Q13

\section{Introduction}

Beef production is recognised in many regions of the world as a branch of production with high importance for agriculture and its development. This is the case in the countries of South America, the United States or Australia, to name a few. In the European Union, its importance is not so high; however, taking into account the years 2013-2016, its increase by almost $5 \%$ can be noticed. A similar situation occurred in the case of consumption, which during the years 2013-2016 increased by almost $4 \%$ (EU Agricultural outlook ..., 2017). Therefore, it can be assumed that the interest taken in its production may increase in the coming years as an alternative to the unstable dairy market. It is important to emphasise the opportunities that agricultural producers intending to beef finishing have in the scope of choosing a production system. As indicated by Deblitz et al. (2008) it is difficult to define the beef production system, but there are some parameters describing this system. These include: geographical location, connection with other branches of agricultural production (dairy, crop production), origin of animals intended for fattening (dairy, cow-calf, percentage of own or purchased), feeding system, sales channels or herd management (start of the fattening period, age of sale cattle, age of animals purchased, etc.).

The purpose of the article is to determine the differences in the economic situation of farms characterised by various beef production systems. Particular attention was paid to production costs. The analysis was based on data from typical farms participating in research carried out by the agri benchmark Beef and Sheep network.

\section{Research results and discussion}

\section{Method and research material}

The research was conducted on the basis of economic and organisational data of beef finishing farms, which are the result of many years of operation of the agri benchmark Beef and Sheep network in 2016. The network was established in 2001 as part of the International Farm Comparison Network. The network is created by scientists, advisers and agricultural producers. Its purpose was to create the basis for analysing agricultural production systems, structural, technological and agricultural policy changes around the world, and facilitating the exchange of information between economists interested in economic analysis at the farm level (Hemme et al., 2014). 
The agri benchmark Beef and Sheep network operates according to strictly defined principles. These principles are obligatory for all entities and relate to the collection and processing of data, the division of costs and the analysis of production costs and the presentation of results (Deblitz C., 2010). The farms participating in the research are an elementary importance for the analyses carried out. These farms are referred to as typical farms defined (together) as:

- being an existing farm or a data set describing a farm;

- farms located in the region with the largest share of farms that produce beef cattle in the total number of farms involved in its production in a given country;

- farms with a production system (combination of production factors) representing the majority of farms in a given country.

Table 1

Calculation and explanation of variables

\begin{tabular}{|l|l|}
\hline \multicolumn{1}{|c|}{$\begin{array}{c}\text { Category of } \\
\text { variable }\end{array}$} & \multicolumn{1}{c|}{ Description/calculation of variable } \\
\hline $\begin{array}{l}\text { Direct costs } \\
\text { enterprises }\end{array}$ & $\begin{array}{l}\text { Purchase of animals, variable cost per head, purchase feed, seed, pesticide, fertiliser, } \\
\text { variable machinery cost, contractor }\end{array}$ \\
\hline Cash costs & $\begin{array}{l}\text { Cash cost for purchased feed, fertiliser, seeds, fuel, maintenance, land rents, interest on } \\
\text { liabilities, wages paid, veterinary costs plus medicine, water, insurance, accounting etc } \\
\text { (excl. VAT) }\end{array}$ \\
\hline Overhead costs & $\begin{array}{l}\text { Cost on whole farm level (fixed cost=e.g. accounting, office) that are allocated to the } \\
\text { enterprises for cost analysis }\end{array}$ \\
\hline $\begin{array}{l}\text { Farm income } \\
\text { (whole farm } \\
\text { profitability) }\end{array}$ & $\begin{array}{l}\text { Market returns (+ coupled payments) (+ decoupled payments) - whole-farm costs +/- } \\
\text { changes in inventory +/-capital gains/losses }\end{array}$ \\
\hline $\begin{array}{l}\text { Net cash farm } \\
\text { income (NCFI) }\end{array}$ & Whole farm profitability + depreciation + changes in inventory + capital gains/losses \\
\hline Total returns & Market returns (+ coupled payments) (+ decoupled payments) \\
\hline $\begin{array}{l}\text { Non-factor costs } \\
\text { (NFC) }\end{array}$ & $\begin{array}{l}\text { All costs except factor costs (labour costs, land costs, capital costs). NFC comprise: } \\
\text { animal purchases, feed (purchase feed, fertiliser, seed, pesticides), machinery } \\
\text { (maintenance, depreciation, contractor), fuel, energy, lubricants, water, buildings } \\
\text { (maintenance, depreciation), vet \& medicine, insurance, taxes, other inputs beef } \\
\text { enterprise (bedding, transport, sales commission, fees, advisory service), other inputs }\end{array}$ \\
\hline
\end{tabular}

Source: author's construction based on Beef Report 2008

In studies of the economic situation of farms, the typical farm method is used by many authors such as: Harwood R. (1979), Dalgaard R. et al. (2006), Trindade H. (2015), Martins A. et al. (2014), Hatch T. et al. (1982), Alig M. (2015), Langemeier M. (2016). As shown by Feuz D. and Skold M. (1990), analyses conducted with the use of the typical farm concept are a very useful tool in the study of farms and can be used by policy makers involved in shaping agricultural policy as well as farmers.

In the calculation of beef production costs, two groups of costs are distinguished: non-factor costs and costs related to factors of production (Table 1). Non-factor costs are expenses incurred by the organisation for the purchase of production resources. These include, among others, feed costs, machinery maintenance costs, fertiliser costs, taxes, etc. The second group of costs includes labour costs, capital costs including the costs of interest on loans and land costs, which include rent or lease costs. Detailed information on the method of calculating individual categories of costs and profitability of beef production is provided in Table 1.

\section{Production costs and profitability of farms producing beef cattle}

The research covered nine typical farms involved in the production of beef from five European Union countries (Table 2). The data on organisational parameters of beef finishing included in 
Table 2 show that the basic determinant of the applied production system is the origin of animals for fattening (Hocquette J. et al., 2011; Vries M. et al., 2015; Oomen J. et al., 1998). It should be noted here that, according to the European Commission DG Agriculture and Rural Development, three types of slaughter cattle farms can be distinguished: "breeders" are farmers with suckler cows not fattening their calves, "breeders \& fatteners" fatten the calves born on their farms, and "fatteners" purchase young male animals and then finish fattening them (EU beef farms report, 2012).

Table 2

Performance indicators of beef finishing

\begin{tabular}{|l|c|c|c|c|c|c|c|c|c|}
\hline \multicolumn{1}{|c|}{$\begin{array}{c}\text { Performance } \\
\text { indicators }\end{array}$} & DE-1 & DE-2 & ES-1 & ES-2 & UK & PL-1 & PL-2 & FR-1 & FR-2 \\
\hline $\begin{array}{l}\text { No. \& type of } \\
\text { beef cattle sold } \\
\text { per year }\end{array}$ & $\begin{array}{c}260 \\
\text { bulls }\end{array}$ & $\begin{array}{c}380 \\
\text { bulls }\end{array}$ & $\begin{array}{c}406 \\
\text { bulls }\end{array}$ & $\begin{array}{c}245 \text { bulls, } \\
235 \\
\text { heifers, } \\
\text { cows }\end{array}$ & $\begin{array}{c}31 \\
\text { steers, } \\
15 \\
\text { heifers }\end{array}$ & $\begin{array}{c}22 \\
\text { bulls }\end{array}$ & $\begin{array}{c}21 \\
\text { bulls, } 9 \\
\text { heifers }\end{array}$ & $\begin{array}{c}35 \text { bulls, } \\
14 \text { cows }\end{array}$ & $\begin{array}{c}200 \\
\text { bulls }\end{array}$ \\
\hline $\begin{array}{l}\text { Origin finishing } \\
\text { cattle (Dairy or } \\
\text { Cow calf) }\end{array}$ & Dairy & Dairy & $\begin{array}{c}\text { Dairy / } \\
\text { Cow- } \\
\text { calf }\end{array}$ & Cow-calf & Cow-calf & $\begin{array}{c}\text { Cow- } \\
\text { calf }\end{array}$ & Dairy & Cow-calf & $\begin{array}{c}\text { Cow- } \\
\text { calf }\end{array}$ \\
\hline $\begin{array}{l}\text { Own (O) or } \\
\text { Purchase (P) }\end{array}$ & $\mathrm{P}$ & $\mathrm{P}$ & $\mathrm{P}$ & $\mathrm{O} / \mathrm{P}$ & $\mathrm{O}$ & $\mathrm{O}$ & $\mathrm{O}$ & 0 & $\mathrm{P}$ \\
\hline $\begin{array}{l}\text { Age at start } \\
\text { (days) }\end{array}$ & 53 & 35 & $\begin{array}{c}30- \\
200\end{array}$ & 195 & 225 & 230 & 15 & 229 & 240 \\
\hline $\begin{array}{l}\text { Finishing period } \\
\text { (days) }\end{array}$ & 494 & 535 & $\begin{array}{c}260- \\
335\end{array}$ & $180-232$ & 467 & 210 & 535 & 235 & 300 \\
\hline $\begin{array}{l}\text { Weight at start } \\
\text { (kg LW) }\end{array}$ & 87 & 83 & $\begin{array}{c}50- \\
175\end{array}$ & $225-240$ & 300 & 290 & 60 & 305 & 312 \\
\hline $\begin{array}{l}\text { Final weight (kg } \\
\text { LW) }\end{array}$ & 721 & 699 & $\begin{array}{c}440- \\
552\end{array}$ & $474-600$ & 670 & 490 & 530 & 600 & 735 \\
\hline $\begin{array}{l}\text { Stocking rate } \\
\text { (LU/ha forage } \\
\text { area) }\end{array}$ & 2,58 & 4,48 & 1,58 & 277,40 & 0,89 & 0,32 & 1,29 & 1,81 & 4,15 \\
\hline
\end{tabular}

Source: author's construction based on agri benchmark Beef and Sheep database

On German and Polish farms, a typical beef production system is based on calves obtained from dairy. In contrast, on Spanish or French ones, fattening of beef cattle breeds is pursued. By analysing the impact of the indicated factor on particular parameters characterising production, one can point to its strict correlation with the age at finishing start. Fattening of the material obtained from dairy production starts between the age of 15 to 53 days and the weight of $60-100 \mathrm{~kg}$. The situation is different with cow-calf such as Limousin (PL-1, FR-1) and Charolais (FR-2). In this case, we deal with weaners aged 6-8 months and most often weighing in at 220-320 kg.

The information shown in Table 2 demonstrates that it is not possible to clearly indicate the relationship between the origin of animals for fattening and the weight when sold to the slaughterhouse. The cattle from typical German farms and from one French farm where the weight was close to or even exceeded $700 \mathrm{~kg}$ was an example of the biggest sale weight. However, on other farms it was in the range of 440-600 kg. The cattle stocking index calculated with the ratio of fattening expressed in cattle livestock unit (LU) and forage area was usually in the range from 0.32 to 4.48. However, its highest level occurred on a Spanish farm and amounted to $277.4 \mathrm{LU} / \mathrm{ha}$, which results from the fact that there occurs intensive industrial fattening (feedlot) on this farm. Feedlot is a component of the production system in which the highest energy consumption per beef production unit and the most intensive land use occurs (Galyean M. et al., 2011). As indicated by 
Ferraz J. and Felicio P. (2010), feedlot is used for about $18 \%$ of beef cattle's life, with the food dose containing a high level of fibre and energy.

Table 3

Farm feed sources

\begin{tabular}{|l|c|c|c|c|c|c|c|c|c|}
\hline \multicolumn{1}{|c|}{ Feed sources } & DE-1 & DE-2 & ES-1 & ES-2 & UK & PL-1 & PL-2 & FR-1 & FR-2 \\
\hline Maize silage & $\mathrm{X}$ & $\mathrm{X}$ & & & $\mathrm{X}$ & $\mathrm{X}$ & $\mathrm{X}$ & $\mathrm{X}$ & $\mathrm{X}$ \\
\hline Straw & & & $\mathrm{X}$ & $\mathrm{X}$ & & & & & \\
\hline Grains & $\mathrm{X}$ & & $\mathrm{X}$ & $\mathrm{X}$ & & $\mathrm{X}$ & $\mathrm{X}$ & $\mathrm{X}$ & \\
\hline Grass silage & & $\mathrm{X}$ & & & & $\mathrm{X}$ & $\mathrm{X}$ & $\mathrm{X}$ & \\
\hline Concentrates & & $\mathrm{X}$ & $\mathrm{X}$ & $\mathrm{X}$ & $\mathrm{X}$ & & $\mathrm{X}$ & & $\mathrm{X}$ \\
\hline
\end{tabular}

Source: author's construction based on agri benchmark Beef and Sheep database

On the examined farms, cattle nutrition was based primarily on maize silage and feed concentrates for cattle (Table 3). Such situation is confirmed, i.e. by the research of Nguyen T. et al. (2010), Ryschawy J. et al. (2012), Oomen J. et al. (1998). Another situation occurs on typical Spanish farms, in which cattle feed includes mainly straw, which is also indicated by Castro $\mathrm{T}$. et al. (2015). On Polish farms, as well as on French and German, feeding doses were also supplemented with grass silage.

The diversified scale and structure of agricultural production influenced the amount of income received by individual farms in 2016 (Table 4). The research conducted shows that farms in which beef cattle accounted for over $70 \%$ of total income were typical farms from Germany, Spain and one from France. On the other hand, on Polish farms or British farms, there occurs a multidirectional production, where the sources of income also include dairy or crop production. Moreover, it can be noticed that there is a lack of connection between the origin of animals destined for fattening and the share of beef finishing returns in whole farm returns. This can be seen by comparing German farms with Spanish or French ones.

The income of farms located in the European Union is supported by the system of direct payments. The share in total revenues in the examined farms ranged from $7 \%$ to over $35 \%$. The analysis shows that the largest share, amounting to over $20 \%$ of direct payments in total returns occurred on Polish, English and French farms, that is on the farms with a small-scale beef production.

The data contained in Table 4 show a high share of direct costs in total costs, reaching over $60 \%$. This situation concerned two-thirds of the surveyed farms in 2016. On Spanish farms these shares were the highest and amounted to almost $90 \%$ of the costs. The remaining types of costs with a significant impact on the profitability of the surveyed farms were overhead costs and depreciation.

The conducted research showed that in all of the analysed farms the agricultural income was positive, however its size was highly diversified. The highest level of income was achieved by German farms in which it exceeded 100.000 USD per farm. After including depreciation into the production costs and calculating net cash farm income, the difference in size is not as huge, especially if we compare German and French farms. This means that German beef farms, which are based on the purchase of calves from dairy incur the highest depreciation costs among all of the analysed typical farms. As shown in Table 4, Polish farms were characterised by one of the lowest incomes. This is confirmed by the report entitled: The EU cattle sector: challenges and 
opportunities-milk and meat made by Ihle R. et al. (2017) on the order of the European Parliament's Committee on Agriculture and Rural Development.

Table 4

Comparison of the beef finishing farms in $\mathbf{2 0 1 6}$ - whole farm figures

\begin{tabular}{|c|c|c|c|c|c|c|c|c|c|}
\hline Indicators & DE-1 & DE-2 & ES-1 & ES-2 & UK & PL-1 & PL-2 & FR-1 & FR-2 \\
\hline \multicolumn{10}{|c|}{ Whole farm returns (1000 USD) } \\
\hline $\begin{array}{l}\text { Market returns } \\
\text { (incl. other farm income) }\end{array}$ & 441 & 521 & 449 & 701 & 174 & 31 & 119 & 162 & 408 \\
\hline Beef finishing & $90 \%$ & $100 \%$ & $100 \%$ & $84 \%$ & $35 \%$ & $48 \%$ & $20 \%$ & $56 \%$ & $77 \%$ \\
\hline Coupled payments & & & 8 & 27 & & 3 & 3 & 12 & \\
\hline Decoupled payments & 33 & 40 & 42 & 86 & 60 & 14 & 29 & 29 & 42 \\
\hline \multicolumn{10}{|c|}{ Whole farm costs (1000 USD) } \\
\hline Direct costs enterprises & 291 & 275 & 426 & 709 & 96 & 27 & 72 & 99 & 288 \\
\hline Overhead costs & 42 & 83 & 34 & 45 & 37 & 8 & 12 & 29 & 48 \\
\hline Paid labour & & 28 & & & 38 & 2 & 10 & & \\
\hline Rents paid & 19 & 47 & 2 & 19 & 17 & 2 & 8 & 5 & 18 \\
\hline Interest paid & 4 & 3 & 0 & 2 & 1 & & 0 & 2 & 8 \\
\hline Depreciation & 52 & 74 & 16 & 31 & 50 & 11 & 7 & 27 & 41 \\
\hline \multicolumn{10}{|c|}{ Whole farm income (1000 USD) } \\
\hline Farm income & 118 & 125 & 37 & 39 & 45 & 9 & 49 & 68 & 88 \\
\hline Net cash farm income & 66 & 51 & 21 & 8 & -5 & -2 & 42 & 41 & 47 \\
\hline
\end{tabular}

Source: author's calculations based on agri benchmark Beef and Sheep database

The amount of beef returns indicates a differentiation in the purchase price of beef cattle in the groups of the "Old and new Union" countries (Table 5). This is confirmed by the beef prices, which were characteristic for Polish farms obtaining a significantly lower beef price in comparison with other ones. The second characteristic feature was that if we exclude Polish farms from the analysis, the beef price on other farms is very similar and does not exceed $0.3 \mathrm{USD} / \mathrm{kg} \mathrm{CW}$.

When analysing the production costs, one can point to lower cash costs on cow-calf origin farms. This can be seen in the comparison of French farms with German farms in which livestock of dairy breeds is kept. The calculations showed that on German farms in 2016 the cash costs were higher by $40-75 \%$ compared to French farms. The difference in costs between beef production systems was also found on Polish farms. On a farm that fattens animals from dairy production, cash costs are almost $25 \%$ higher than on a cow-calf origin farms. A similar situation occurs when Spanish farms are analysed. The cash costs of the feedlot farms are approx. 50 USD/100 kg CW lower compared to the farms which conduct fattening of both cow-calf and dairy origin.

The data contained in Table 5, detailing shares of particular types of expenses in production costs, indicate close relationship between the production system and cattle nutrition and the amount of feed costs. On cow-calf origin farms, where the basis for feeding is maize silage, the costs of feed are lower than on farms based on material derived from dairy production. This fact can be observed by comparing Polish and German farms with French and British farms. In the majority of surveyed farms, the share of feed costs in beef production expenses did not exceed $50 \%$, but this situation did not apply to Spanish farms in which the share was higher. This is due to the specific feeding system of cattle on these farms, where straw is the basic fodder. The costs of maintaining machinery and equipment also had a high impact on the production costs on cowcalf origin farms. In the majority of analysed farms, the share of these costs ranged from $30 \%$ to 
$40 \%$ (Spanish farms being the only exception). On the other hand, on farms which fattened dairy cattle breeds, it did not exceed $20 \%$.

Table 5

Comparison of the beef finishing farms in $\mathbf{2 0 1 6}$ - beef finishing enterprise

\begin{tabular}{|c|c|c|c|c|c|c|c|c|c|}
\hline Return/cost figures & DE-1 & DE-2 & ES-1 & ES-2 & UK & PL-1 & PL-2 & FR-1 & FR-2 \\
\hline \multicolumn{10}{|c|}{ Returns - absolute values (USD/100 kg CW sold) } \\
\hline Beef returns & 363 & 363 & 383 & 383 & 390 & 250 & 283 & 376 & 367 \\
\hline Total returns & 365 & 363 & 385 & 385 & 407 & 260 & 302 & 376 & 367 \\
\hline \multicolumn{10}{|c|}{ Costs of the beef enterprise excl. animal purchases (USD/100 kg CW sold) } \\
\hline Non-factor costs incl. depreciation & 221 & 235 & 242 & 199 & 286 & 262 & 225 & 184 & 160 \\
\hline Depreciation & 45 & 51 & 13 & 16 & 109 & 87 & 13 & 59 & 39 \\
\hline Cash costs & 193 & 238 & 230 & 184 & 282 & 207 & 255 & 136 & 135 \\
\hline \multicolumn{10}{|c|}{ Non-factor costs excl. animal purchases - percentage composition } \\
\hline $\begin{array}{l}\text { Feed (purchase feed, fertiliser, } \\
\text { seed, pesticides) }\end{array}$ & $47 \%$ & $38 \%$ & $72 \%$ & $65 \%$ & $17 \%$ & $34 \%$ & $43 \%$ & $24 \%$ & $33 \%$ \\
\hline $\begin{array}{l}\text { Machinery (maintenance, } \\
\text { depreciation, contractor) }\end{array}$ & $20 \%$ & $18 \%$ & $5 \%$ & $4 \%$ & $37 \%$ & $29 \%$ & $5 \%$ & $36 \%$ & $34 \%$ \\
\hline Fuel, energy, lubricants, water & $9 \%$ & $14 \%$ & $4 \%$ & $4 \%$ & $6 \%$ & $19 \%$ & $29 \%$ & $9 \%$ & $9 \%$ \\
\hline $\begin{array}{l}\text { Buildings (maintenance, } \\
\text { depreciation) }\end{array}$ & $11 \%$ & $18 \%$ & $3 \%$ & $7 \%$ & $22 \%$ & $12 \%$ & $4 \%$ & $11 \%$ & $8 \%$ \\
\hline Vet \& medicine & $2 \%$ & $4 \%$ & $3 \%$ & $7 \%$ & $2 \%$ & $1 \%$ & $5 \%$ & $5 \%$ & $3 \%$ \\
\hline Insurance, taxes & $4 \%$ & $3 \%$ & $3 \%$ & $2 \%$ & $4 \%$ & $3 \%$ & $3 \%$ & $5 \%$ & $4 \%$ \\
\hline Other inputs beef enterprise & $4 \%$ & $4 \%$ & $5 \%$ & $8 \%$ & $7 \%$ & $0 \%$ & $10 \%$ & $6 \%$ & $5 \%$ \\
\hline Other inputs & $2 \%$ & $1 \%$ & $3 \%$ & $4 \%$ & $6 \%$ & $2 \%$ & $1 \%$ & $4 \%$ & $4 \%$ \\
\hline
\end{tabular}

CW=Carcass Weight

Source: author's calculations based on agri benchmark Beef and Sheep database

\section{Conclusions, proposals, recommendations}

1) A characteristic feature of farms involved in the production of beef in the European Union is that the cattle comes from two sources. Therefore, farms specializing in calf fattening are distinguished, which in most cases have calves from their own suckler cows herd. Another case is the connection of beef production with milk production. In the European Union, three types of farms breeding cattle for slaughter are distinguished: "breeders" "breeders \& fatteners" and "fatteners".

2) On typical European farms one can encounter farms specializing in the production of beef, as well as farms in which this type of production is one of the many directions of agricultural production. The conducted research has shown that in farms with high specialization there is a lower level of production costs, especially if fattening of beef cattle is conducted. This should encourage agricultural producers who decide to beef production to adopt such business strategy.

3) The expenses that had the greatest impact on the cost of beef production in the surveyed farms were the feed costs and machine maintenance (including outsourced services). Often, the indicated types of expenses accounted for over $70 \%$ of production costs. Therefore, they should raise special interest among agricultural producers, as they have a significant impact on the profitability of beef production and can become a source of competitive advantage.

\section{Bibliography}

1. Alig, M., Sutter, M., Nemecek T. (2015). Eco-efficiency of Grass-based Dairy Systems in Switzerland.

Grassland Science in Europe, Volume 20, Wageningen: Wageningen Academic Publishers, pp. 380-385.

2. Beef Report 2008 (2008). Agri benchmark Beef Network. Brauschweig, Germany, pp. 3-40. 
3. Castro, T., Cabezas, A., De la Fuente, J., Isabel, B., Manso, T., Jimeno V. (2015). Animal Performance and Meat Characteristics in Steers Reared in Intensive Conditions Fed with Different Vegetable Oils. Animal, 10(3), pp. 520-530.

4. Dalgaard, R., Halberg, N., Kristensen, Ib., Inger Larsen, I. (2006). Modelling Representative and Coherent Danish Farm Types based on Farm Accountancy Data for use in Environmental Assessments. Agriculture, Ecosystems and Environment, 117 (2006), pp. 223-237.

5. De Vries, M., Middelaar, C., De Boer, J. (2015). Comparing Environmental Impacts of Beef Production Systems: A review of Life Cycle Assessments. Livestock Science 178 (2015), pp. 279-288.

6. Deblitz, C. (2010). Agri benchmark: Benchmarking Beef Farming Systems Worldwide. Conference (54th), February 10-12, 2010, Adelaide, Australia. Retrieved: https://econpapers.repec.org/paper/agsaare10/59096.htm. Access: 04.02.2018.

7. Deblitz, C., Brömmer, J., Bruggemann, D. (2008). Beef Production in Germany - Production Systems and Their Spatial Distribution. Landbauforschung - vTI Agriculture and Forestry Research 1/2 (58), pp. 29-44.

8. EU Agricultural Outlook for the Agricultural Markets and Income 2017-2030 (2017). European Union. p. 86.

9. EU Beef Farms Report 2012 (2013). European Union, p. 3.

10. Ferraz, J., Felicio, O. (2010). Production Systems - An Example from Brazil. Meat Science 84, pp. $238-243$.

11. Feuz, D., Skold, M. (1990). Typical Farm Theory in Agricultural Research. Department of Economics Staff Paper Series, Paper 75. Retrieved:http://openprairie.sdstate.edu/econ_staffpaper/75. Access: 04.02.2018.

12. Galyean, M., Ponce, C., Schutz, J. (2011). The Future of Beef Production in North America. Animal Frontiers 1, pp. 29-36.

13. Harwood, R. (1979). Small Farm Development. Understanding and Improving Farming Systems in the Humid Tropics. Boulder, Colorado: Westview Press, Inc., p. 9.

14. Hatch, T., Gustafson, C., Baum, K., Harrington, D. (1982). A Typical Farm Series: Development and Application to a Mississippi Delta Farm. Journal of Agricultural and Applied Economics, Vol. 14, Issue 02, pp. 31-36.

15. Hemme, T., Uddin, M., Ndambi, O. (2014). Benchmarking Cost of Milk Production in 46 Countries. Journal of Reviews on Global Economics, Volume 3, pp. 254-270.

16. Hocquette, J. F., Chatellier, V. (2011). Prospects for the European Beef Sector over the next 30 years. Animal Frontiers, Vol. 1, No. 2, pp. 20-28.

17. Ihle, R., Dries, L., Jongeneel, R., Venus, T., Wesseler, J. (2017). Research for AGRI Committee - The EU Cattle Sector: Challenges and Opportunities - Milk and Meat. European Union.

18. Langemeier, M. 2016. International Benchmarks for Soybean Production. Farmdoc daily (6):171, Department of Agricultural and Consumer Economics, University of Illinois at Urbana-Champaign, September 9, 2016.

19. Martins, A., Goldsmith, P., Moura, A. (2014). Managerial Factors Affecting Post-harvest Loss: the Case of Mato Grosso Brazil. International Journal of Agricultural Management, Volume 3, Issue 4, pp. 200-209.

20. Nguyen, T., Hermansen, J., Mogensen, L. (2010). Environmental Consequences of Different Beef Production Systems in the EU. Journal of Cleaner Production 18, pp. 756-766.

21. Oomen, G., Lantinga, E., Goewie, E., Van der Hock (1998). Mixed Farming Systems as a Way Towards a More Efficient Use of Nitrogen in European Union Agriculture. Environmental Pollution 102, SI (1998), pp. 697-704.

22. Ryschawy, J., Choisis, N., Choisis, J., Joannon, A., Gibon, A (2012). Mixed Crop-livestock Systems: An Economic and Environmental-Friendly Way of Farming? Animal (2012), 6:10, pp. 1722-1730.

23. Trindade H. (2013). Portuguese Dairy Farming Systems. Grassland Science in Europe, Volume 20, Wageningen: Wageningen Academic Publishers, pp. 21-25. 